\title{
Respon Gamma Glutamil Transpeptidase ( $\gamma$-GT) dan Kadar Glukosa Sapi Perah pada Ketinggian Tempat (Altitude) yang Berbeda
}

\author{
Respon of Gamma Glutamiltranspeptidase $(\gamma-G T)$ and Glucose \\ in Dairy Cattle of Different Altitude \\ U. Hidayat Tanuwiria*, D. Tasrifin, A. Mushawwir \\ Fakultas Peternakan Universitas Padjadjaran \\ Kampus Jatinangor Jl. Raya Bandung-Sumedang Km. 21, Sumedang, \\ Jawa Barat, 45363 \\ *Korespondensi E-mail: hidayat.tanuwiria@gmail.com
}

\begin{abstract}
ABSTRAK
Sembilan puluh ekor ternak sapi perah dengan umur laktasi ke-3, 4 dan ke-5 masing-masing 30 ekor, telah digunakan dalam penelitian ini, yang dipelihara pada tiga level ketinggian tempat, yaitu 350-500 m dpl, 550-750 m dpl dan >800 $\mathrm{m}$ dpl, untuk mengetahui pengaruh ketinggian tempat dan umur laktasi terhadap respon gamma glutamil transpeptidase dan kadar glukosa plasma darah sapi perah. Sampel darah telah dilakukan sebanyak dua kali, pada vena pangkal ekor, menggunakan tabung EDTA dan syringe $5 \mathrm{~mL}$. Gamma glutamil transpeptidase dan glukosa telah dianalisis menggunakan petunjuk dan protocol berdasarakan KIT BIOLABO. Hasil penelitian menunjukkan bahwa respon gamma glutamil transpeptidase menurun $(\mathrm{P}<0,05)$ dengan meningkatnya ketinggian tempat, sedangkan kadar glukosa meningkat dengan meningkatnya umur laktasi, tetapu tidak terhadap ketinggian tempat.
\end{abstract}

Kata kunci: Altitude, Sapi Perah

\begin{abstract}
Ninety dairy cattle with a lactation age of 3rd, 4th and 5th, 30 each, have been used in this study, which are maintained at three levels of altitude, namely 350$500 \mathrm{~m}$ above sea level ( $\mathrm{m}$ asl), 550-750 $\mathrm{m}$ asl and $>800 \mathrm{~m}$ asl, to determine the effect of altitude and age of lactation on the gamma response of glutamyl transpeptidase and blood glucose levels in dairy cows. Blood samples were carried out twice, at the base of the tail vein, using EDTA tubes and a $5 \mathrm{~mL}$ syringe. The data that was collected, analyzed using IBM SPSS 21 software. Gamma glutamyl transpeptidase and glucose were analyzed using guidelines and protocols based on the BIOLABO KIT. The results showed that the gamma glutamyl transpeptidase response decreased $(\mathrm{P}<0.05)$ with increasing altitude, whereas glucose levels increased with increasing age of lactation, but not to elevation or altitude.
\end{abstract}

Keywords : Altitude, Dairy cattle 


\section{PENDAHULUAN}

Jawa Barat merupakan salah satu provinsi sebagai sentra pengembangan dan budidaya sapi perah serta sebagai penghasil susu di Indonesia. Populasi ternak sapi perah di Jawa Barat menyebar di berbagai lokasi pemeliharaan dengan range altitude (ketinggian tempat) yang luas (rendah hingga tinggi). Dalam perkembangannya, kondisi fisik makro lingkungan, tidak lagi menjadi pertimbangan utama, meskipun zona thermoneutral bagi sapi perah dalam range temperatur $18-23^{\circ} \mathrm{C}$.

Temperatur dan kelembaban lokasi pemeliharaan, secara makro sangat dipengaruhi oleh ketinggian tempat. Ketinggian tempat yang rendah memiliki temperatur lingkungan yang lebih tinggi dibandingkan dengan lokasi pada ketinggian tempat yang lebih tinggi dari permukaan laut. Kondisi ini diperparah kondisi global sekarang ini yaitu terjadinya peningkatan rata-rata temperature permukaan bumi.

Profil faktor fisik lingkungan (topografi, temperatur dan kelembaban) secara langsung mempengaruhi kinerja fisiologi ternak sapi perah. Lokasi pemeliharaan yang bertemperatur yang tinggi menyebabkan dissipasi panas dari tubuh ke lingkungan semakin tinggi. Ini disebabkan oleh radiasi panas kepada tubuh ternak semakin tinggi. Kenyataan lain menunjukkan bahwa upaya penyesuaian panas semakin sulit dilakukan apabila lokasi pemeliharaan, selain bertemperatur tinggi juga disertai kelembaban yang tinggi.

Sebagai ternak homotermik, maka keadaan homeostasis merupakan alternatif satusatunya untuk mempertankan metabolisme sel yang normal, meskipun dalam kondisi minim. Homeostasis ini ditempuh melalui mekanisme kerja system organ, terutama mempertahan temperatur tubuh normal.

Jantung dan ginjal merupakan organ yang sangat berperan dalam meregulasikan dan mengevaporasi panas tubuh melalui konservasi cairan tubuh ekstraseller yaitu darah, baik melalui keringat maupun dengan urine. Mekanisme kerja organ yang berlebihan menyebabkan peningkatan peradangan hingga kematian sel-sel jantung dan ginjal. Kerusakan sel-sel menyebabkan pelepasan ensim gamma glutamyl transpeptidase $(\gamma-G T)$, sehingga enzim ini meningkat kadarnya di dalam plasma darah.

Faktor fisik makro lingkungan juga secara langsung mempengaruhi aktivitas antioksidan. Keadaan yang mencekam yang mampu ditolerir oleh ternak, menyebabkan stimulasi enzim antioksidan atau antioksidan endogen. Glutation merupakan salah satu 
antioksigen endogen. Prekursor pembentukannya adalah glukosa-6-diphospat yang dikatalis dari glukosa. Ini berarti bahwa kondisi fisik lingkungan juga mempengaruhi profil glukosa, dalam kepentingan antioksidan maupun sebagai buffer cairan ekstraselluler.

Penelitian ini telah dilakukan untuk mengetahui dan mengkaji dampak variasi ketinggian tempat dan umur laktasi terhadap respon enzim gamma glutamyl transpeptidase $(\gamma-G T)$ dan kadar glukosa pada sapi perah.

\section{METODE}

\section{Ternak dan Lokasi Penelitian}

Sembilan puluh ekor ternak sapi perah dengan umur laktasi ke-3, 4 dan ke-5 masingmasing 30 ekor, telah digunakan dalam penelitian ini. Lokasi penelitian menyebar di Provinsi Jawa Barat, di tiga lokasi berdasarakan topografi, yaitu :

1. Lokasi dengan topografi 350-500 dpl : Kabupaten Sukabumi

2. Lokasi dengan topografi 550-750 dpl : Kabupaten Sumedang

3. Lokasi dengan topografi $>800 \mathrm{dpl} \quad$ : Kabupaten Bandung

Sebelum dimulai penelitian, telah dilakukan terlebih dahulu penentuan altitude dengan melakukan pengukurn altitude (ketinggian tempat). Ketinggian tempat diukur dengan menggunakan altimeter tipe EK-Fan, dengan kemampuan pengukuran -700 sampai dengan 9000 meter $(-2300 \sim 2950 \mathrm{ft})$, dengan deviasi akurasi hasil pengukuruan yaitu 1 sampai dengan 3 meter.

Ternak percobaan terdiri dari 30 ekor pada tiap-taip lokasi topografi, terdiri dari masing-masing 10 ekor sapi perah berumur laktasi III, IV dan V. Ternak percobaan dipelihara secara intensif. Pemberian pakan terdiri dari hijauan dan konsentrat. Air minum diberikan secara adlibitum.

\section{Pengambilan sampel, Pengukuran $\gamma$-GT dan Glukosa}

Pengambilan sampel darah telah dilakukan dengan menggunakan syringe dan tabung ber-EDTA $5 \mathrm{~mL}$. Darah dikoleksi dari vena pangkal ekor, sebanyak dua kali berselang satu bulan. Darah yang telah dikoleksi, dicentrifuge di Laboratorium Fisiologi Ternak dan Biokimia, Fakultas Peternakan, untuk memisahkan plasma darahnya. Plasma darah yng diperoleh, dipisahkan dengan menggunakan kuvet plasma berukuran $3 \mathrm{~mL}$.

Plasma yang telah diperoleh dianalisis untuk mengukur konsentrasi $\gamma$-GT dan glukosanya. Analisis kadar kedua parameter ini telah dilakukan berdasarakan prosedur dan 
petunjuk KIT BIOLABO. Pengukuran konsentrasi $\delta$-GT dalam plasma darah dilakakuan dengan mengikuti prosedur berikut :

Dipipet ke dalam cuvette yang bersakala $1 \mathrm{~cm}$ :

\begin{tabular}{l|l}
\hline Reagent & $1 \mathrm{~mL}$ \\
\hline Dibiarkan suhu $37^{\circ} \mathrm{C}\left(30^{\circ} \mathrm{C}\right)$ kemudian ditambahkan: \\
\hline Specimen & $50 \mu \mathrm{L}$ \\
\hline absorbansi dicatat setelah 30 detik pada panjang gelombang $405 \mathrm{~nm}$. Absorbansi dicatat \\
setiap menit selama 3 menit. Kemudian dihitung perubahan absorbansi per menit \\
$(\Delta$ Abs/min)
\end{tabular}

Konsentrasi $\gamma$-GT dikalkulasi berdasarkan data absorban sampel dan standar, menggunakan formula, yaitu IU $/ \mathrm{L}=(\Delta \mathrm{Abs} / \mathrm{min}) \times 2121$.

Kadar glukosa darah dianalisis dengan mengikuti prosedur sebagai berikut :

\begin{tabular}{lccc}
\hline \multicolumn{1}{c}{ Bahan } & Blank & Standard & Assay \\
\hline Reagent & $1 \mathrm{~mL}$ & $1 \mathrm{~mL}$ & $1 \mathrm{~mL}$ \\
\hline Demineralised water & $10 \mu \mathrm{L}$ & & \\
\hline Standard & & $10 \mu \mathrm{L}$ & $10 \mu \mathrm{L}$ \\
\hline Specimen & & &
\end{tabular}

Dibiarkan selama 5 minutes pada temperatur $37^{\circ} \mathrm{C}$ atau selama 10 menit pada suhu ruangan. Absorbans telah dibaca pada $\lambda 500 \mathrm{~nm}$

Konsentrasi glukosa dikalkulasi berdasarkan data absorban sampel dan standar, menggunakan formula berikut :

$$
\text { Kalkulasi }=\frac{\text { Abs (Assay) }}{\text { Abs (Standard) }} \times \text { Konsentrasi Standard }
$$

Kondisi fisik lingkungan juga telah direkor antara lain temperatur dan kelembaban kandang, juga dicatat selama penelitian setiap pagi, siang dan malam menggunakan sebuah recorder automatis digital yang dipasang disetiap lokasi dan kandang peneltian. Pada akhir penelitian, file hasil rekor temperatur, kelembaban dan indeks temperatur-kelembaban dipindahkan ke komputer.

\section{Analisis Data}


Data hasil pengukuran yang telah diperoleh selama penelitian, kemudian dianalisis dengan teknik statistika menggunakan Uji Perbandingan Kruskal Wallis. Teknik analisis dan interpretasi datanya telah dilakukan dengan menggunakan software SPSS IBM 21.

\section{HASIL DAN PEMBAHASAN}

Tabel 1. Kadar $\gamma$-Glutamil Transpeptidase $(\gamma-G T)$ dan Glukosa Sapi Perah pada Berbagai Altitute (Ketinggian Tempat)

\begin{tabular}{cllll}
\hline \multirow{2}{*}{ Umur Laktasi } & \multirow{2}{*}{ Respon } & \multicolumn{3}{c}{ Katinggian Tempat/Altitude (m dpl) } \\
\cline { 3 - 5 } & & $350-500$ & $550-750$ & $>800$ \\
\hline \multirow{2}{*}{ III } & $\gamma$-GT (IU/L) & $49,46 \pm 1,58^{\mathrm{aA}}$ & $47,74 \pm 1,84^{\mathrm{bA}}$ & $46,83 \pm 2,04^{\mathrm{bA}}$ \\
\cline { 2 - 5 } & Glukosa $(\mathrm{mg} / \mathrm{dL})$ & $08,85 \pm 0,84^{\mathrm{aA}}$ & $08,04 \pm 0,17^{\mathrm{aA}}$ & $07,55 \pm 0,46^{\mathrm{aA}}$ \\
\hline \multirow{2}{*}{ IV } & $\gamma$-GT (IU $/ \mathrm{L})$ & $49,83 \pm 2,63^{\mathrm{aA}}$ & $47,03 \pm 1,87^{\mathrm{bA}}$ & $46,73 \pm 1,49^{\mathrm{bA}}$ \\
\cline { 2 - 5 } & Glukosa $(\mathrm{mg} / \mathrm{dL})$ & $09,73 \pm 0,54^{\mathrm{aA}}$ & $09,25 \pm 0,32^{\mathrm{aA}}$ & $10,52 \pm 0,72^{\mathrm{aB}}$ \\
\hline \multirow{2}{*}{ V } & $\gamma$-GT (IU $/ \mathrm{L})$ & $51,75 \pm 2,86^{\mathrm{aB}}$ & $50,40 \pm 1,63^{\mathrm{aA}}$ & $47,13 \pm 1,37^{\mathrm{bA}}$ \\
\cline { 2 - 5 } & Glukosa $(\mathrm{mg} / \mathrm{dL})$ & $10,83 \pm 0,84^{\mathrm{aB}}$ & $10,28 \pm 0,63^{\mathrm{aB}}$ & $11,86 \pm 0,52^{\mathrm{bC}}$
\end{tabular}

Keterangan : - Nilai rata-rata pada baris yang sama, yang diikuti abjad kecil yang berbeda menunjukkan perbedaan yang nyata $(\mathrm{P}<0,05)$

- Nilai rata-rata pada kolom dan respon yang sama, yang diikuti abjad kapital yang berbeda menunjukkan perbedaan yang nyata $(\mathrm{P}<0,05)$

Lokasi pemeliharaan dengan ketinggian tempat (altitude) yang berbeda sangat terkait faktor fisik lingkungan seperti temperatur dan kelembaban, semakin rendah altitude maka semakin tinggi temperatur lingkungannya. Demikian pula sebaliknya, temperatur lingkungan yang rendah atau dingin dirasakan oleh ternak pada lokasi peeliharaan dengan dataran yang lebih tinggi.

Temperatur lingkungan sangat berpengaruh terhadap kondisi fisiologik ternak, kondisi ini dapat diperparah apabila terjadi kombinasi temperatur dan kelembaban yang keduanya tinggi. Ternak sapi perah, sebagai ternak yang homotermik harus mampu melakukan penyesuaian temperatur tubuhnya dengan temperatur lingkungan. Pengaturan atau regulasi tubuh dalam penyesuaian kondisi fisik lingkungan dengan temperatur tubuh, melibatkan seluruh organ tubuh (Mushawwir dkk., 2010; Mushawwir dan Latifudin, 2011; 2012; Pearce dkk., 2013). 
Pelibatan organ-organ tubuh dalam mencapai homeostasis panas tubuh, direspon oleh organ tubuh dengan derajat aktivitas berbeda. Upaya thermoregulasi ini tampak direspon oleh organ lebih intensif, melalui peningkatan denyut jantung dan frekuensi kerja system pernafasan yang lebih tinggi (Tan dkk., 2010; Wang dkk., 2007; Won dkk., 2012), kemudian dimanifestasikan dengan disertai temperatur permukaan tubuh dan temperatur rektal yang lebih tinggi (Mushawwir dkk., 2010; 2011). Kondisi fisiologik menggambarkan bahwa interaksi organ dalam pengaturan panas dan mempertahankan milio internal tubuh sangat diperlukan dan karena itu merupakan mekanisme fisiologik dan biokimiawi yang sangat berat. Sebagai dampak adalah kebutuhan energi yang lebih banyak (Mushawwir dan Latifudin, 2012), kebutuhan nutrient dalam ransum basal harus semakin kompleks (Tanuwiria, 2004; 2007a; 2007b; Adawiah dkk., 2007; Tanuwiria dkk., 2011), pencernaan serat kasar menurun (Tanuwiria dkk., 2007) dan laju perombakan precursor non karbohidrat menjadi pyruvate (glukoneogenesis) meningkat (Mushawwir, 2015; Ramadhina dkk., 2019) dan perubahan profil metabolisme karbohidrat (Adriani dan Mushawwir, 2008; Mushawwir dkk., 2011; ) serta peningkatan kadar radikal bebas seperti ROS (Mujahid dkk., 2007; Latipudin dan Mushawwir, 2011; Mushawwir dkk., 2017).

Terkait dengan fenomena lokasi pemeliharaan dengan ketinggian tempat yang berbeda, tampak respon spesifik terkait fungsi jantung dan metabolisme mengalami perubahan-perubahan. Pada Tabel 1, tampak bahwa kadar gamma glutamil transpeptidase $(\gamma$-GT) lebih tinggi $(\mathrm{P}<0,05)$ pada kelompok sapi yang dipelihara diketinggian tempat lebih rendah dibandingkan pada kelompok sapi yang dipelihara pada altitude lebih tinggi. Fenomena ini terjadi pada semua kelompok sapi dengan umur laktasi yang berbeda.

Diketahui bahwa ensim $\gamma$-GT merupakan enzim yang konsentrasi banyak terdapat di dalam sel-sel jaringan jantung. Terkait dengan altitude seperti telah diuraikan sebelumnya bahwa altitude yang lebih rendah memiliki temperatur yang tinggi. Usaha homeostasis yang melibatkan kerja jantung (Shinder dkk., 2007; Roland dkk., 2016) dalam rangka penyediaan energi (Rhoads dkk., 2013) berdampak terhadap peningkatan kematian sel-sel jantung (nekrosis). Beberapa penelitian terdahulu menunjukkan bahwa nekrosis meningkat dengan terjadinya peningkatan temperatur lingkungan terhadap ternak sapi (Rhoads dkk., 2013; Bova dkk., 2014; Nguyen dkk., 2016), pada unggas (Mushawwir dkk., 2018).

Peningkatan kematian sel-sel jantung seiring dengan peningkatan temperatur berdampak terhadap peningkatan migrasi enzim $\gamma$-GT ke system pembuluh, sehingga 
meningkatkan kadar enzim ini di dalam plasma darah. Hasil penelitian terdahulu menunjukkan bahwa kematian sel-sel (nekrosis) menyebabkan peningkatan migrasi metabolit ke system pembuluh (Mushawwir dan Latipudin, 2013; Ipplito dkk., 2014). Hasil penelitian ini juga menunjukkan bahwa kadar enzim $\gamma$-GT tampak meningkat pada kelompok sapi perah dengan bertambahnya umur laktasi, pada lokasi pemeliharaan dengan altitude yang rendah, yait 49,46 IU/L pada kelompok sapi berumur laktasi III menjadi lebih tinggi $(\mathrm{P}<0,05)$ pada kelompok sapi dengan umur laktasi ke-5 yaitu 51,75 IU/L. Meskipun fenomena ini tidak terjadi pada kelompok-kelompok sapi perah yang dipelihara pada altitude $>700 \mathrm{~m}$ dpl. Slimen dkk. (2016) telah melaporkan bahwa kematian sel-sel (baik nekrosis maupun apoptosis) semakin meningkat dengan meningkatnya metabolisme dan umur.

Hasil penelitian sebelumnya juga menunjukkan bahwa ternak yang dipelihara dalam zona temperatur yang sesuai dengan zona thermoneutral zone sapi perah menyebabkan tidak terjadinya stimulasi terhadap pengaktifan hormon epinefrin dari nor-epinefrin menjadi epinefrin (Allen dkk., 2015; Mushawwir dkk., 2017) yang dipicu oleh neurotransmitter karena stimulasi reseptor syaraf (Ippolito dkk, 2014). Hormon amin ini (epinefrin) merupakan senyawa penyinal bagi reseptor alfa-epenifrin di dinding-dinding sistem pembuluh darah (Shinder dkk., 2007; Mushawwir, 2015; Saidah dan Mushawwir, 2015; Slimen dkk., 2016) yang menyebabkan peningkatan vasodilatasi atau pelebaran dinding pembuluh darah (Mujahid dkk, 2007) dan memacu denyut jantung meningkat (Wang dkk., 2007).

Hasil penelitian ini (Tabel 1) juga menunjukkan terjadinya peningkatan $(\mathrm{P}<0,05)$ kadar glukosa semua kelompok sapi perah yang dipelihara pada lokasi ketinggian tempat yang berbeda. Peningkatan kadar glukosa terjadi seiring dengan meningkatnya umur laktasi ternak. Perubahan ini dapat disebabkan sebagai dampak masih terjadinya pertumbuhan jaringan sehingga kapasitas sintesis lipid masih terus meningkat (Tian dkk., 2015), peningkatan metabolisme karena jaringan bertambah massanya (Siregar dkk., 2020), peningkatan massa liver dan menyebabkan peningkatan gluconeogenesis (Sahara dkk., 2019; Azizah dkk., 2020; Mistiani dkk., 2020; Nurazizah dkk., 2020).

Terkait dengan peningkatan kapasitas biosintesis air susu oleh sel-sel alveol di jaringan mammae, sudah tentu terkait dengan prekursor pembentukan air susu (Hebly dkk., 2014). Kebutuhan prekurosor yang tinggi dapat menstimulan peningkatan pembentukan glukosa 
dari berbagai sumber, seperti protein (Mushawwir dkk., 2018; Dinana dkk., 2019), dan bahkan mendorong peningkatan metabolisme di rumen (Pangestu dkk., 2003; Tian dkk., 2015; Mutaqin dkk., 2019).

\section{KESIMPULAN}

Berdasarkan hasil penelitian dan pembahasan dapat disimpulkan bahwa altitude atau ketinggian tempat mempengaruhi respon gamma glutamil transpeptidase $(\gamma-G T)$ dan kadar glukosa plasma darah sapi perah. Respon $\gamma$-GT menurun dengan meningkatnya altitude, meskipun tidak diikuti dengan peningkatan atau penurunan glukosa. Glukosa mengalami peningkatan konsentrasi seiring dengan meningkatnya umur laktasi pada berbagai ketinggian tempat.

\section{DAFTAR PUSTAKA}

Adawiah, A., Sutardi, T., Toharmat, T., Manalu, W., Ramli, N., dan Tanuwiria, U.H. 2007. Respons terhadap suplementasi sabun mineral dan mineral organik serta kacang kedelai sangrai pada indikator fermentabilitas ransum dalam rumen domba. Media Peternakan, 30, 62-69.

Adriani, L. dan Mushawwir, A. 2008. Kadar Glukosa Darah, Laktosa dan Produksi Susu Sapi Perah pada Berbagai Tingkat Suplementasi Mineral Makro. Fakultas Peternakan Universitas Padjadjaran.

Allen, J.D., Hall, L.W., Collier, R.J., and Smith, J.F. 2015. Effect of core body temperature, time of day, and climate conditions on behavioral patterns of lactating dairy cows experiencing mild to moderate heat stress. J. Dairy Sci, 98, 118-27.

Azizah, T.R.N., Singgih, D.P., Setiyatwan, H., Widjastuti, dan Asmara, I.Y. 2020. Peningkatan pemanfaatan ransum pada ayam sentul yang diberi ekstrak buah mengkudu (morinda citrifolia) dengan suplementasi tembaga dan seng. Jurnal Nutrisi Ternak Tropis dan Ilmu Pakan, 2, 25-34.

Bova, T.L, Chiavaccini, L., and Cline, G.F. 2014. Environmental stressors influencing hormones and systems physiology in cattle. Reprod Biol. Endocrinol,12, 58.

Dinana, A., Latipudin, D., Darwis, D., dan Mushawwir, A. 2019. Profil enzim transaminase ayam ras petelur yang diberi kitosan iradiasi. Jurnal Nutrisi Ternak Tropis dan Ilmu Pakan, 1 (1), 6-15.

Hebly, M., De Ridder, D., de Hulster, E.A.F., De la Torre Cortes, P., Pronk,J.T., and Lapujade, P.D. 2014. Physiological and transcriptional responses of anaerobic chemostat cultures of Saccharomyces cerevisiae subjected to diurnal temperatur cycles. Appl. E Environm. Microbiol, 80, 4433-4449.

Ippolito, D.L, Lewis, J.A., Yu, C., Leon, L., and Stallings, J.D. 2014. Alteration in circulating metabolites during and after heat stress in the conscious rat: potential biomarkers of exposure and organspecific injury. BMC Physiol, 14, 14.

Latipudin, D. dan Mushawwir, A. 2011. Regulasi panas tubuh ayam ras petelur fase grower dan layer. Jurnal Sains Peternakan Indonesia, 6, 77-82. 
Mistiani, S., Kamil, K.A. dan Rusmana, D. 2020. Pengaruh tingkat pemberian ekstrak daun burahol (stelechocarpus burahol) dalam ransum terhadap bobot organ dalam ayam broiler. Jurnal Nutrisi Ternak Tropis dan Ilmu Pakan, 2,42-50.

Mujahid, A., Akiba, Y., \& Toyomizu, M. 2007. Acute heat stress induces oxidative stress and decreases adaptation in young white leghorn cockerels by down regulation of avian uncoupling protein. Poultry Sci, 86, 364-371.

Mushawwir A. dan D. Latipuddin. 2013. Biologi Sintesis Telur, Perspektif Fisologi, Biokimia dan Molekuler Produksi Telur. Penerbit Graha Ilmu, Yogyakarta.

Mushawwir, A., Tanuwiria, U.H., Kamil, K.A., Adriani, L., and Wiradimadja, R. 2017. Effects of volatile oil of garlic on feed utilization, blood biochemistry and performance of heat-stressed Japanese quail. Asian Journal of Poultry Science, 11, 83-89.

Mushawwir, A., Tanuwiria, U.H., Kamil, K., Adriani, L., Wiradimadja, R., and Suwarno, N. 2018. Evaluation of haematological responses and blood biochemical parameters of heat-stressed broilers with dietary supplementation of javanese ginger powder (Curcuma xanthorrhiza) and garlic extract (Allium sativum). International J of Poultry Sci, 17, 452-458.

Mushawwir, A. 2015. Biokimi Nutrisi. Widya Padjadjaran, Bandung.

Mushawwir, A. dan Latipudin, D. 2011. Beberapa parameter biokimia darah ayam ras petelur fase grower dan layer dalam lingkungan "Upper Zonathermoneutral". Jurnal Peternakan Indonesia, 13, 191-198.

Mushawwir, A. dan Latipudin, D. 2012. Respon fisiologi thermoregulasi ayam ras petelur fase grower dan layer. Proceeding of National Seminar on Zootechniques, 1(1), 23-27.

Mushawwir, A.,Yong, Y.K., Adriani, L., Hernawan, E., and Kamil, K.A. 2010. the fluctuation effect of atmospheric ammonia $\left(\mathrm{NH}_{3}\right)$ exposure and microclimate on hereford bulls hematochemical. J. of the Indon Tropical Anim Agric, 35, 232-238.

Mushawwir, A., Adriani, L., and Kamil, K.A. 2011. prediction models for olfactory metabolic and sows\% rnareticulocyt (rnart) by measurement of atmospheric ammonia exposure and microclimate level. J of the Indon Tropical Anim Agric, 36, 1420.

Mutaqin, B.K., D. S. Tasripin, L. Adriani, U. H.Tanuwiria. 2019. Effect of the addition of CaPUFA complexes to complete rations on fermentability and digestibility. Pakistan Journal of Nutrition, 18, 519-523.

Nguyen, T.T., Bowman, P.J., Haile-Mariam, M., Pryce, J.E., and Hayes, B.J. 2016. Genomic selection for tolerance to heat stress in Australian dairy cattle. J. Dairy Sci, 99, 2849-62.

Nurazizah, N., Nabila, A.I., Adriani, L., Widjastuti, T., dan Latipudin, D. 2020. Kadar kolesterol, urea, kreatinin darah dan kolesterol telur ayam sentul dengan penambahan ekstrak buah mengkudu yang disuplementasi Cu dan Zn. Jurnal Nutrisi Ternak Tropis dan Ilmu Pakan, 2, 9-18.

Pangestu, E., Toharmat, T., and Tanuwiria, U.H. 2003. Nilai nutrisi ransum berbasis limbah industri pertanian pada sapi perah laktasi. J. Indon. Trop. Anim. Agric, 28, 166-171.

Pearce, S. C., Gabler, N.K., Ross, J.W., Escobar, J., Patience, J.F., Rhoads, R.P., and Baumgard, L.H. 2013. The effects of heat stress and plane of nutrition on metabolism in growing pigs. J. Anim. Sci, 91.

Ramadhina, I.A., Adriani, L., dan Sujana, E. 2019. Pengaruh pemberian ekstrak daun kepel (Stelechocarpus burahol) terhadap kadar kolesterol darah dan telur puyuh (Coturnixcoturnix japonica). Jurnal Nutrisi Ternak Tropis dan Ilmu Pakan, 1, 34-40.

Rhoads, R.P., Baumgard, L.H., and Suagee, J.K. 2013. Metabolic priorities during heat stress with an emphasis on skeletal muscle. J. Anim. Sci, 91, 2492-2503. 
Roland, L, Drillich, M., Klein-Jobstl, D., and Iwernes, M. 2016. Invited review: Influence of climatic conditions on the development, performance, and health of claves. J. Dairy Sci, 99,2438-52.

Sahara, E. S. Sandi, M.L. Sari. 2019. Dampak pemberian tepung bawah putih terhadap profil lipid liver dan plasma darah puyuh yang mengalami cekaman panas. Jurnal Nutrisi Ternak Tropis dan Ilmu Pakan, 1, 16-24.

Saidah, I.N. dan Mushawwir, A. 2015. Mortalitas embrio dan daya tetas itik lokal (Anas sp.) berdasarkan pola pengaturan temperatur mesin tetas. Jurnal E-Student, 4:5-11.

Shinder, D., Rusal, M., Tanny, J., Druyan, S., and Yahav, S. 2007. Thermoregulatory responses of chicks (Gallus domesticus) to low ambient temperatures at an early age. Poult. Sci, 86, 2200-2209.

Siregar, R.H., Latipudin, D., dan Mushawwir, A. 2020. Profil lipid darah ayam ras petelur yang di beri kitosan iradiasi. Jurnal Nutrisi Ternak Tropis dan Ilmu Pakan, 2,1-8.

Slimen, B, Najar, T., Ghram, A., and Abdrranna, M. 2016. Heat stress effects on livestock: molecular, cellular and metabolic aspects, a review. J Anim Physiol Anim Nutr, 100, 401-12.

Tan, G.Y., Yang, L., Fu, Y.-Q., Feng, J.H., and Zhang, M.H. 2010. Effects of different acute high ambient temperatures on function of hepatic mitochondrial respiration, antioxidative enzymes, and oxidative injury in broiler chickens. Poultry Science, 89, 115-122.

Tanuwiria, U.H. 2004. Efek suplementasi $\mathrm{Zn}-\mathrm{Cu}$ proteinat dalam ransum terhadap fermentabilitas dan kecernaan in vitro. Jurnal Ilmu Ternak, 4, 7-12.

Tanuwiria, U.H. 2007a. Proteksi protein tepung ikan oleh berbagai sumber tannin dan pengaruhnya terhadap fermentabilitas dan kecernaannya (in vitro). J. Agroland, 14, 56-60.

Tanuwiria, U.H., 2007b. Efek suplementasi kompleks mineral-minyak dan mineral-organik dalam ransum terhadap kecernaan ransum, populasi mikroba rumen dan performa produksi domba jantan. Prosiding Seminar Nasional dan Kongres Asosiasi Ahli Nutrisi. AINI, 1, 23-27.

Tanuwiria, U.H., Santosa, U., Yulianti, A.A., and Suryadi, U. 2011. The Effect of organic-Cr dietary supplementation on stress response in transport-stressed beef cattle. J. Indon. Trop. Anim. Agric, 36, 97-103

Tanuwiria, U.T., Mushawwir, A., dan Yulianti, A.A. 2007. Potensi pakan serat dan daya dukungnya terhadap populasi ternak ruminansia di wilayah kabupaten Garut. Jurnal Ilmu Ternak, 7, 11-16.

Tian, H., Wang, W., and Zheng, N. 2015. Identification of diagnostic biomarkers and metabolic pathway shifts of heat-stressed lactating dairy cows. J. Proteomics, 125, 1728.

Wang, S. C., Chen, J., Huang, Y., Li, X.F., and Zhang, D.J. 2007. Effect of heat stress on production performance and blood biochemical indices in broiler. China Poult, 15, 11 13.

Won, S. G. L., Xie, G., Boddicker, R., Rhoades, J.N., Lucy, M.C., Safranski, T.J., Selsby, J.T., Lonergan, S., Baumgard, L.H., Ross, J.W and Rhoads, R.P. 2012. Acute duration heat stress alters expression of cellular bioenergetic-associated genes in skeletal muscle of growing pigs. J. Anim. Sci, 90 (E-Suppl. 3), 573. 